\title{
Slovenčina pre študentov medicíny
}

\author{
Radoslav Ďurajka
}

\begin{abstract}
Abstrakt: Autor predstavuje novú učebnicu pre zahraničných študentov medicíny „SLOVENČINA pre študentov medicíny“, jej koncepciu so zameraním na špecifiká vyučovania jazyka v nefilologickom odbore. Opisuje jednotlivé časti knihy, uvádza modifikované príklady gramatiky a zároveň upriamuje pozornost' na ciel' výučby - zvládnut' komunikáciu v bežnom živote, na univerzite, ale najmä v medicínskej praxi, preto tematicky čerpá najmä z tohto prostredia.
\end{abstract}

Klúčové slová: slovenčina ako cudzí jazyk, komunikácia s pacientmi, gramatika

Abstract: The author introduces a new textbook for foreign students of medicine „SLOVAK for medical students", its conception focusing on the specifics of language teaching in the nonphilological field. The author describes particular parts of the book, gives modified examples of grammar and draws attention to the goal of teaching - to master communication in everyday life, at the university, but especially in medical practice, thus selects the topics mainly from this environment.

Key words: Slovak as a foreign language, communication with patients, grammar;

Kniha Slovenčina pre študentov medicíny bola tvorená „na mieru“ študentom medicíny Lekárskej fakulty Univerzity Komenského v Bratislave kolektívom autorov pôsobiacich na Ústave cudzích jazykov, ${ }^{1}$ kde sa okrem vyučovania latinskej lekárskej terminológie $\mathrm{v}$ odboroch všeobecné lekárstvo, zubné lekárstvo (vrátane anglického programu) a biomedicína, vyučuje cudzí jazyk (anglický jazyk) a slovenčina ako cudzí jazyk.

Pri tvorbe učebnice mali autori na zreteli najmä komunikáciu s pacientom a špecifiká vyučovania $\mathrm{v}$ nefilologickom odbore. To znamená, že ciel'om je študentova schopnost' komunikovat' s pacientmi v nemocnici, odoberat' anamnézu, zist'ovat' symptómy pacienta, viest’ dialóg smerujúci k diagnóze pacienta - a to po absolvovaní iba štyroch semestrov výučby slovenského jazyka. Na základe porovnania hodinovej dotácie a reálnych časových možností je zrejmé, že sa lektori musia

\footnotetext{
${ }^{1}$ História Ústavu cudzích jazykov LF UK siaha do roku 1953 ked’ bola založená Celouniverzitná katedra cudzích jazykov. 0 desat' rokov neskôr sa táto centralizovaná inštitúcia pretransformovala na samostatné katedry jazykov, pričom oddelenia jazykov lekárskej a farmaceutickej fakulty existovali pod spoločným vedením až do r. 1981. Významným momentom sa stal rok 1991, ked' sa na Lekárskej fakulte UK vytvorila katedra jazykov, ktorá pod názvom Ústav cudzích jazykov LF UK funguje dodnes. Medzi d’alšie aktivity pracovníkov patria odborné jazykové semináre pre doktorandské štúdium, podiel’anie sa na výbere študentov, ktorí majú záujem o študijné pobyty a stáže v zahraničí, preverovanie znalostí z cudzieho jazyka (angličtina, nemčina) a v neposlednom rade pomoc dekanátu, študijnému oddeleniu, jednotlivým pracoviskám pri prekladoch. Pracovisko rozvíja kontakty s domácimi i zahraničnými partnermi a inštitúciami (v Čechách, v Bulharsku, v Slovinsku, v Mad’arsku) najmä v rámci ERASMUS+.
} 
primárne sústred'ovat' na hlavný ciel' - na komunikáciu. ${ }^{2}$ Nie je vel’a priestoru na rozvíjanie všeobecnej slovnej zásoby, či prílišné upevňovanie gramatických pravidiel. Pre medikov (nefilológov) sú, napr. genetické znaky slovenčiny či kontrastívne porovnania s ostatnými (ne)slovanskými jazykmi, doplňujúce (ak nie absolútne marginálne), no spolu s históriou, historickým vývinom slovenčiny a etymológiou pomáhajú odpovedat' na časté otázky osvojovatelov: „Prečo je to tak? Ako je to možné? Prečo to neexistuje $v$ „našom “jazyku?" a zdôvodňujú tak dnešný stav slovenčiny $\mathrm{v}$ jednotlivých jazykových rovinách. Táto oblast' ale netvorí integrálnu súčast' výučby, čím sa podstatne líši od štúdia slovakistov, slavistov a filológov. Zo špecifík vyučovania slovenčiny pre medikov spomeňme aspoň tie najmarkantnejšie:

a) hodinová dotácia a postavenie jazyka v systéme výučby;

(kurz je povinný $2 \times 2$ hodiny týždenne počas štyroch semestrov a v piatom semestri študenti začínajú svoju odbornú prax v nemocnici, nedostatočné kreditové ohodnotenie kurzu je pre študentov často demotivujúce)

b) spoločné znaky všetkých študentov;

(rovnaké miesto, stupeň a typ vzdelávacej inštitúcie, charakter a zameranie jazykového vzdelávania, mentálna zaneprázdnenost' medikov aj ich nepripravenost' na nový (malý) cudzí jazyk, neobmedzené možnosti kontaktu s nositel'mi osvojovaného jazyka, zmenená sociálna rola)

c) angličtina - nematerinský jazyk lektora i študentov;

(nemožnost' vychádzat' zo vzájomných vztahov slovenčiny a východiskového jazyka každého študenta, t. j. že vyučovanie je čiastočne založené na porovnávaní slovenčiny s angličtinou, využívajúc tiež anglicizmy/internacionalizmy $\mathrm{v}$ slovenčine)

d) osobitná didaktika;

(jednoduchost' a praktickost', efektivita počas vyučovacích hodín, dodržiavanie špecifického obsahového zamerania, praktický nácvik komunikácie, priatel'ská atmosféra, prepojenie a nadväznost' počas všetkých semestrov, rozlišovanie pasívnej a aktívnej slovnej zásoby)

e) odbornost' a sústredenie sa na realitu.

(lektor zodpovedá nielen za jazykové, ale aj za odborné znalosti a študent popri tom nesmie zabúdat’ na realitu, ktorá im pomáha pri pochopení jazyka - obézny muž nemôže vážit' devätnást' ale devät'desiat kilogramov ....). ${ }^{3}$

Kniha Slovenčina pre študentov medicíny predstavuje stručné základy jazyka, ktoré ale reflektujú praktické a konverzačné zameranie učebnice. Tematický čerpá z vysokoškolského medicínskeho prostredia a pomáha tak naplnit' primárny ciel'

\footnotetext{
2 Predpokladaná dotácia pre úroveň B1 a B2 je 100 vyučovacích hodín, reálne je k dispozícii cca 72 h.

3 Porovnaj: Slovenčina ako cudzí jazyk na Lekárskej fakulte Univerzity Komenského v Bratislave. In: CASALC review. Roč. 6, č. 3 (2017), s. 5-17
} 
- zvládnut' komunikáciu v bežnom živote, na univerzite, ale najmä v medicínskej praxi. Je akýmsi odrazovým mostíkom pre d’alšie štúdium i samoštúdium. Skladá sa z troch častí. Základná čast' obsahuje motivačnú nultú kapitolu a desat' kapitol. Nultá kapitola, Slovenčina - prvá pomoc, je nezávislou častou a malou praktickou príručkou slovenčiny pre úplných začiatočníkov. Jej cielom je poskytnút' študentom užitočné vety a frázy, ktoré môžu ihned' používat' v rôznych každodenných situáciách, s ktorými sa stretnú. Nachádza sa tu i slovenská abeceda s l'ahko identifikovatel'nými slovami (injekcia, hotel, fraktúra). Následné cvičenia na správnu výslovnost' sa tak stávajú jednoduchšími. Ústredný slovensko-anglický text sa snaží študentovi ukázat', že slovenčine je možné rozumiet' i bez jej poznania/zvládnutia.

„As a študent, after arriving in Slovensko and getting to know your univerzita, you will probably look for a good pub, bar, bufet, kaviareň or reštaurácia. If you are hungry in Slovensko, forget about diéta, just ask for the menu and order: pizza, špagety, lasagne, kebab, hot dog, steak, sendvič, tortilla, burger, hemendex, šalát ... before you try something traditional. You can have kečup or majonéza too." (Ďurajka a kol., 2018, 11).

Všetky lekcie sú rovnako štruktúrované, sú členené do štyroch častí (A, B, C, D), pričom čast' D je zameraná na medicínsku terminológiu (l'udské telo, prvá pomoc, lekáreň ...). Jednotlivé kapitoly sa zameriavajú na prezentáciu gramatických pravidiel a rozvoj jazykových zručností potrebných pre bežnú komunikáciu. Tematicky vychádzajú z bežného života študenta medicíny a nadväzne z potrieb jeho medicínskej praxe. Klúč $\mathrm{k}$ cvičeniam ani zvukové záznamy textov nie sú súčastou učebnice, pretože je primárne určená na prácu s lektorom počas vyučovacích hodín. Cielom je tiež podporit' aktívne zapojenie študentov do riešenia úloh, ich iniciatívne vyhladávanie zdrojov a možností komunikovat' v reálnych situáciách, využívanie internetu a médií pre autonómne vzdelávanie sa.

Na úrovni gramatiky sa vytvoril priestor pre potenciálne prepojenie všeobecných gramatických pravidiel a špecifického ciela osvojenia si jazyka s ohladom na využitie v lekárskom prostredí. V deklinácií substantív sa zaviedli vzory, ktoré sú terminologicky bližšie medicínskej praxi a študenti si tak upevňujú pravidlá priamo na potrebnej lexike. Vzory M - pacient, kolega, mobil, počítač; F - pacientka, nemocnica, dlaň a kost'; N - koleno, srdce, oddelenie, dievča.

Pri časovaní slovies sa berie do úvahy nielen ich výber, ale s ohladom na formálnu komunikáciu, ktorú si má študent osvojit', sa predovšetkým sústred'ujeme na prvú osobu singuláru (Mám problém. Vidím zle. Cítim sa zle), tretiu osobu singuláru (Dcéra má problém. Syn vidí zle. Manželka sa necíti dobre.) a druhú osobu plurálu (Ako sa máte? Vidíte dobre? Cítite sa zle?). Samozrejme, že je snaha, aby študent ovládal formálnu aj neformálnu komunikáciu, avšak s ohladom na hodinovú dotáciu sa prikláňa k pragmatickej výučbe so zameraním na vytýčený finálny ciel' - 
teda viest' dialóg smerovaný k diagnóze (Máte bolesti? Kde vás to bolí? Aká je to bolest'? Kedy začala? ...). Študenti tiež musia:

a) tvorit' imperatív - inštrukcie pre pacienta (Dýchajte zhlboka! Zavrite oči. Predpažte ...);

b) aktívne tvorit' otázky v minulom, prítomnom čase (Boli ste operovaný/á? Mali ste kiahne? Vyskytla sa vo vašej rodine cukrovka? Aký máte problém? Máte suchý kašel'? Máte hypertenziu v rodine? ...);

c) v budúcom čase najmä opísat', čo budú robit’ (Popočúvam vás Zoberiem vám ster. Odmeriam vám tlak.)

V lekciách je citel'ná snaha o jednoduchost' a vyzdvihnutie pravidelnosti jazyka. ${ }^{4}$ Neskôr sa, samozrejme, dopĺn̆ajú i výnimky a nepravidelnosti. Koncentrovanie sa na pravidelnost' $\mathrm{v}$ jazyku pomáha minimalizovat' počiatočnú demotiváciu študenta pri strete s novým (často nepríbuzným - rozumej slovanským) jazykovým systémom.

Nadväznost' a zároveň postupnost' od jednoduchšieho k zložitejšiemu tiež možno vidiet' na poradí základných gramatických celkov ${ }^{5}$ a javov (napr. verbá imperatív - kedže sa imperatív tvorí z 3. os. plurálu alebo napr. stupňovanie adverbií stupňovanie adjektív - kedže pri adverbiách nepotrebujeme rod) i tém bežnej komunikácie (rodina, Bratislava, na hodine, jedlo, cestovanie, vol'ný čas, moja krajina, počasie, párty ...).

Druhou čast’ou učebnice je sekcia VIAC a hrá dôležitú úlohu pri dopĺňaní, rozširovaní a precvičovaní primárnych textov a javov zo základnej časti. Nadväznost' k lekcii je vyjadrená formou odkazu na príslušnú stranu. Na konci sekcie sa nachádza HUDOBNÁ BANKA. Využitie týchto doplnkových materiálov je možné prispôsobit' potrebám študentov a časovým možnostiam.

Nachádzajú sa tu rôzne typy úloh (opravte, doplňte, transformujte, preložte, čítajte, spojte, odpovedajte ...) ale i doplnkové vysvetlenie gramatiky (napr. pluráliá tantum v tretej lekcii).

Tret'ou čast'ou tejto publikácie je SLOVNÁ BANKA zameraná na poskytnutie potrebnej slovnej zásoby z jednotlivých oblastí medicíny a následne poskytuje otázky a odpovede typické pre komunikáciu lekár - pacient pri odoberaní anamnéz.

\footnotetext{
${ }^{4}$ Napríklad genitív plurálu neutier a femín je vysvetlený vzorcom: skrátit’ a predížit': hlavy 1) hlav 2) hláv.

5 1. lekcia: rody, 2. lekcia: verbá, 3. lekcia: plurál a imperatív, 4. lekcia: minulý čas, 5. lekcia: lokál, 6. lekcia: inštrumentál, 7. lekcia: budúci čas, 8. lekcia: adjektíva, 9. lekcia: datív, 10. lekcia: genitív.
} 
Základná lexika o l'udskom tele ${ }^{6}$ sa d'alej rozvíja cez témy: symptómy, choroby, úrazy ... Každá čast' sa snaží nadviazat’ na kapitolu v prvej časti učebnice a zároveň poskytuje priestor na precvičenie si osvojovanej slovnej zásoby a zároveň sa snaží tému rozvinút' aj po gramatickej stránke. Jednoduché cvičenia (zorad'te chronologicky, spojte opozitá, doplňte vety, zakrúžkujte správnu odpoved') sa prelínajú so zložitejšími. Napríklad: $Z$ verb na predchádzajúcej strane vyberte imperfektívne a použite vo vete; alebo $\mathrm{Z}$ dvojice slov (štádia života) si jedno vyberte a napíšte, čím je toto obdobie charakteristické.

$\mathrm{V}$ rámci tejto časti učebnice sú prítomné i niektoré anamnézy, ktoré majú rovnakú štruktúru (opakovanie slovnej zásoby) súvisiacich a už prebratých tém; okruhy tém $\mathrm{k}$ danej anamnéze (zároveň je to i pomôcka $\mathrm{k}$ ústnej skúške); práca vo dvojiciach / v skupine). Poslednou čast'ou je text, ktorý tematicky dopĺňa alebo rozširuje danú tému a je, samozrejme, doplnený úlohami na zistenie porozumenia textu.

V prípade potreby alebo časových možností, sa na konci učebnice nachádzajú DOPLNKOVÉ MATERIÁLY, napr. dotazník darcu krvi, ošetrovatel'stvo, detské a infekčné choroby ... Kedže pri výučbe využívame kazuistiky, ${ }^{7} \mathrm{v}$ učebnici nachádzame iba jednu - Astma. Pomocou osnovy PA-SY-VY-DIA-LI-S (pacient - symptómy - vyšetrenia - diagnóza - liečba - stav pacienta) sa študenti zdokonalujú v prerozprávaní textu vlastnými slovami.

Poslednou prílohou tejto publikácie je slovensko-anglický slovník. Pri substantívach je uvádzaný rod a forma plurálu, napríklad: študentka, F-ky. Pri verbách je, okrem základného tvaru neurčitku a tvaru 1. os. j. č. doplnená aj informácia, či je verbum (im)perfektívne. Anglicko-slovenskú čast' slovník neobsahuje.

Namiesto záveru si dovolíme konštatovat', že učebnica chcela prispiet' ku kvalitnejšej jazykovej príprave zahraničných študentov medicíny na Lekárskej fakulte UK $\mathrm{v}$ Bratislave, kedže počas svojej praxe $\mathrm{v}$ nemocnici musia hovorit' po slovensky. Túto základnú motiváciu (absolvovanie praxe) sme chceli podporit’ lepšou jazykovou pripravenostou, a to najmä zjednodušením gramatických pravidiel, poukázaním na pravidelnosti v jazyku, využívaním lekárskej terminológie v každej časti učebnice. Zároveň je kniha akousi základňou pre d’alšie štúdium. V budúcnosti na ňu bude nadväzovat' vydanie dalšej (komunikatívne zameranej) učebnice. Uvedomujeme si, že v budúcnosti bude určite potrebná jej modifikácia a doplnenie.

\footnotetext{
${ }^{6}$ L’udské telo je dokonalé aj pre jazykové vzdelávanie. Nachádzame tu pravidelný i nepravidelný plurál, plurália tantum, farby a v neposlednom rade jednoduché precvičovanie všetkých pádov: napr: A - l'udské telo má ..., L - krv je v ..., I - nos je nad ..., G - močovody vedú moč z ... do ...,

7 Odborná slovenčina v medicínskej praxi - kazuistiky. Slovak in medical practice - case reports. Bratislava: UK, 2014. 75 s. ISBN 978-80-223-3608-6
} 


\section{Použitá literatúra}

BALKovÁ, D. (2014). Odborná slovenčina v medicínskej praxi - kazuistiky. Slovak in medical practice - case reports. Bratislava, Slovensko: UK.

ĎURAJKA, R. (2017). Slovenčina ako cudzí jazyk na Lekárskej fakulte Univerzity Komenského v Bratislave. CASALC review, 6(3), 5-17.

ĎurajKa, R., HalákovÁ, M., JAMrichovÁ, V. (2018). Slovenčina pre študentov medicíny. Bratislava, Slovensko: UK.

PekARovičovÁ, J., ŽıgovÁ, L', MoŠATovÁ, M. (2007). Slovenčina ako cudzí jazyk - Vzdelávací program Slovenčina ako cudzí jazyk - jazykový kurz v kontaktnej a dištančnej forme. Bratislava: Stimul. Dostupné z: https://fphil.uniba.sk/fileadmin/fif/katedry_pracoviska/sas/Publikacie/Vzdelavaci_program.pdf

\section{Autor}

Mgr. Radoslav Ďurajka, PhD., Ústav cudzích jazykov LF UK V Bratislave,

e-mail: radoslav.durajka@fmed.uniba.sk,

Autor pôsobí ako odborný asistent na Lekárskej fakulte UK v Bratislave a zameriava sa na slovenčinu ako cudzí jazyk, najmä špecifiká vyučovania jazyka v nefilologickom odbore. Ďalšie lektorské skúsenosti pri výučbe cudzincov získal v rámci letnej školy slovenského jazyka a kultúry Studia Academica Slovaca, počas stáže na Hankuk University of Foreign Studies v Južnej Kórei i na Filozofickej fakulte UK, kde obhájil dizertačnú prácu „Osvojovanie si slovenčiny ako cudzieho jazyka v kontexte psycholingvistiky a didaktiky“. 